\title{
Perempuan, Media Digital, dan Penguatan Ekonomi di Masa Pandemi Covid 19
}

\author{
Empowering Women in the Use Digital Media for Economic Strengthening in Pandemic Time \\ Covid 19
}

Yulianti*
Andalusia Neneng Permatasari
Muthiah Umar
Dede Lilis Chaerowati
Department of Communication
Sciences, Universitas Islam
Bandung, Bandung, West Java,
Indonesia
email: yulianti@unisba.ac.id
Kata Kunci
Media digital
Pelaku usaha kecil
Pemberdayaan
Perempuan
Keywords:
Digital media
Empowerment
Small business actors
Women
Accepted: September 2021
Published: January 2022

\begin{abstract}
Abstrak
Wabah virus covid 19 telah mempengaruhi semua aspek kehidupan tanpa terkecuali. Krisis ekononomi sudah nampak di depan mata, dan memerlukan kerjasama semua pihak, termasuk kaum perempuan. Tidak akan ada pemberdayaan yang berkelanjutan tanpa melibatkan kaum perempuan. Sejalan dengan hal tersebut, Organisasi Aisyiyah Kota Bandung tampil sebagai garda terdepan dalam upaya mengokohkan perekonomian perempuan. Pendekatan yang digunakan dalam pemberdayaan ini yaitu Asset Based Community Development (ABCD). Fokus pemberdayaan dititik beratkan pada optimalisasi potensi pemberdayaan ekonomi khususnya bagi perempuan di Kota Bandung. Pelatihan dan pendampingan dari mulai pentingnya memahami fungsi media digital untuk pengembangan usaha, pembuatan konten untuk membuat jejaring dan promosi, hingga praktik menggunakan media digital secara optimal dilakukan. Hasil pemberdayaan menunjukkan bahwa terjadi peningkatan kognisi secara signifikan pada perempuan Aisyiyah Kota Bandung. Pemberdayaan seperti ini kendaknya dijadikan sesuatu yang terus berkelanjutan.
\end{abstract}

\begin{abstract}
The Covid 19 virus outbreak has affected all aspects of life without exception. The economic crisis is in sight and requires the cooperation of all parties, including women. There will be no sustainable empowerment without involving women. In line with this, the Bandung City Aisyiyah Organization appears as the vanguard to strengthen the women's economy. The approach used in this empowerment is Asset Based Community Development (ABCD). The focus of empowerment is focused on optimizing the potential for economic empowerment, especially for women in the city of Bandung. Training and assistance, starting from the importance of understanding the function of digital media for business development, creating content for networking and promotion, to the practice of using digital media optimally. The empowerment results show a significant increase in cognition in Aisyiyah women in Bandung. Empowerment like this should be made sustainable.
\end{abstract}

(C) 2022 Yulianti, Andalusia Neneng Permatasari, Muthiah Umar, Dede Lilis Chaerowati. Published by Institute for Research and Community Services Universitas Muhammadiyah Palangkaraya. This is Open Access article under the CC-BY-SA License (http://creativecommons.org/licenses/by-sa/4.0/). DOI: https://doi.org/10.33084/pengabdianmu.v7i1.2286

\section{PENDAHULUAN}

Penurunan pertumbuhan ekonomi dunia terjadi selama pandemi Covid 19. Begitu pula kondisi perekonomian Indonesia yang merosot tajam. Hal itu terlihat dari lebih lambatnya pertumbuhan ekonomi pada tahan 2020, ketika pandemi Covid 19 baru terjadi, yaitu 2,97\%. Sebagaimana data dari Badan Pusat Statistik (BPS) yang menyatakan kondisi pelambatan pertumbuhan ekonomi Indonesia mencapai 2,97\% (year on year). Ditambah terjadinya peningkatan pemutusan hubungan kerja sebesar 212.394 pekerja yang terkena PHK (Indayani \& Hartono, 2020).

Perempuan menjadi penggerak ekonomi atau "Women as Economic Drivers". Perempuan mempunyai peran penting dalam beradaban manusia. Islam juga memandang perempuan sebagai aset dunia dan akhirat pada konteks yang berfaedah, serta 
memposisikan perempuan pada puncak keistimewaan (Hanafi \& Sobirin, 2002). Banyak perempuan yang tampil dan berperan dalam kehidupan bermasyarakat, berbangsa, dan bernegara yang salah satunya adalah sebagai perempuan pengusaha. Perempuan mengambil peran tidak hanya memperkuat ketahanan ekonomi keluarga dan masyarakat tetapi juga mengurangi efek fluktuatif ekonomi, berkontribusi dalam upaya penurunan angka kemiskinan serta menjamin pertumbuhan ekonomi yang berkelanjutan (Indiworo, 2016).

Jumlah absolut pengusaha perempuan di Indonesia sangat tinggi. Kendati demikian, mayoritas pengusaha perempuan di negara berkembang khususnya Indonesia, masih beroperasi di usaha kecil dan mikro dengan pertumbuhan yang sangat kecil. Pada tahun 2011, Kementerian Pemberdayaan Perempuan dan Perlindungan Anak memperkirakan ada 55.206.444 usaha mikro, kecil, dan menengah (UMKM), di mana 60\%, atau 33 juta, dimiliki oleh perempuan, mewakili hampir seperempat dari angkatan kerja aktif (Chib et al., 2015). Data dari Kementrian Koperasi dan UKM pada tahun 2015 tercatat, dari sekitar 52 juta pelaku UKM yang ada di seluruh Indonesia, sebanyak 60\% usaha dijalankan oleh perempuan. Kewirausahaan perempuan berpotensi sebagai motor utama pendorong proses pemberdayaan wanita dan transformasi sosial (Tambunan, 2012). Partisipasi perempuan dalam berwirasausaha agar dapat mandiri menunjukkan perkembangan yang cukup pesat.

Salah satu organisasi perempuan di Indonesia yang banyak bergerak di bidang sosial dan memiliki kepeduliaan atas kesenjangan gender ialah Aisyiyah Muhammadiyah. Organisasi ini merupakan pergerakan perempuan Muhammadiyah dalam segala aspek kehidupan, yakni pendidikan, kesehatan, sosial, ekonomi dan dakwah. Pimpinan Daerah Aisyiyah Kota Bandung yang memiliki 18 cabang menaungi anggota dan kader perempuan yang memiliki potensi usaha ekonomi ini, di antaranya berwirausaha produk telor asin, kue kering, jus segar, catering, abon, roti, kerudung, sayuran serta buahbuahan segar, dan lain-lain. Beberapa di antara perempuan Aisyiyah, ada juga yang menjadi reseller pada salah produk, dan ada juga yang memiliki seutuhnya wirausaha tersebut. Tentu saja hal ini sangat didukung oleh Pimpinan Daerah Aisyiyah Kota Bandung. Apalagi saat ini Aisyiyah secara struktur juga memiliki divisi perekonomian yang disebut Majelis Ekonomi yang berfungsi untuk mengkoordinasikan kegiatan perekonomian di tiap pimpinan daerah, cabang dan ranting. Bentuk nyata Majelis Ekonomi ini ialah dengan memiliki gerakan ekonomi yang disebut BUEKA, yakni Bina Usaha Ekonomi Keluarga Aisyiyah.

Pemanfaatan media digital dalam rangka penguatan ekonomi ini tentu sangat dibutuhkan agar usaha yang telah dirintis oleh para anggota dan kader Pimpinan Daerah Aisyiyah Kota Bandung agar bisa bertahan hidup di masa pandemi covid19 ini. Walaupun sebagian besar kader perempuan Aisyiyah sudah mengetahui cara menggunakan media sosial atau $e-$ commerce, tetapi optimalisasi pemanfaatannya masih kurang dan banyak kendala. Kesenjangan gender (gender gap) semakin kuat karena kurangnya pendidikan yang dimiliki para pengusaha perempuan. Bukan hanya pendidikan formal, tetapi juga pendidikan non-formal seperti pelatihan kewirausahaan dan bisnis yang masih langka diperoleh kaum perempuan (Vivakaran \& Maraimalai, 2017). Untuk mengatasi permasalahan tersebut, maka diperlukan pendampingan kepada kader perempuan Aisyiyah Kota Bandung, khususnya para pelaku usaha kecil untuk memanfaatkan media digital sebagai media penguatan perekonomian.

\section{METODE}

Pemberdayaan perempuan dalam memanfaatkan media digital untuk penguatan ekonomi di masa pandemi Covid 19 dilakukan dengan pendekatan ABCD (Assets Based Community Development) (Anas \& Ferrara, 2004). Ada lima langkah kunci yang harus dilakukan, yakni:

1. Discovery (Menemukan)

Pimpinan Daerah Aisyiyah Kota Bandung seperti telah dijelaskan sebelumnya telah memiliki Majelis Ekonomi dan gerakan ekonomi yang bernama BUEKA. Langkah discovery ini pada program PKM ini dilakukan dengan wawancara kepada Pimpinan Daerah Aisyiyah Kota Bandung dan anggota-anggotanya untuk menemukan aset dan potensi yang dimiliki. 
2. $\quad$ Dream (Impian)

Pada tahap dream, wawancara kembali dilakukan untuk mengetahui impian atau keinginan dari mereka untuk perkembangan pengetahuan (capacity change), sikap (behavior change), dan impact yang dicapai setelah kegiatan PKM ini. Hal ini berfungsi untuk merancang langkah-langkah kegiatan untuk memenuhi impian dan harapan tersebut.

3. Design (Merancang)

Langkah selanjutnya adalah proses merencanakan langkah strategis untuk dapat mencapai harapan yang telah diidentifikasi pada tahap dream, yakni pelatihan, pendampingan, monitoring, dan evaluasi.

4. Define (Menentukan)

Setelah merancang kegiatan PKM yang tepat dan sesuai harapan dari mitra, ditentukan topik besar dari pendampingan yang akan dilakukan. Tahap ini dilakukan bersamaan dengan tahap design karena pada tahap design dilakukan penentuan-penentuan untuk setiap tahapan kegiatan PKM ini.

5. Destiny (Lakukan)

Tahap ini adalah tahap akhir dari pendampingan, yaitu langkah pengerjaan untuk segala hal yang telah direncanakan dan dirancang untuk memenuhi harapan dan impian dari mitra. Pada tahapan ini, langkah-langkah yang telah didesain dan dirancang secara konkret dilakukan.

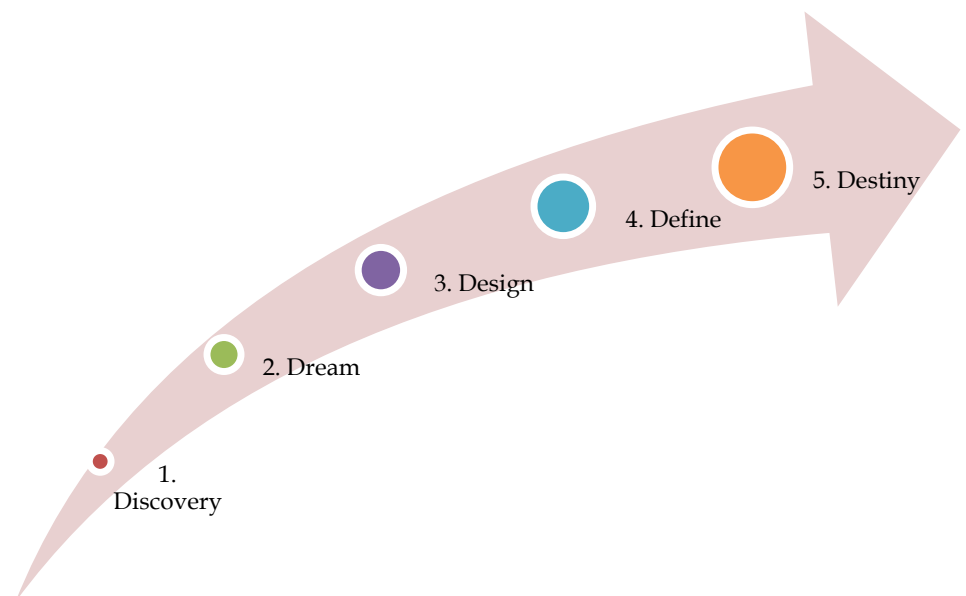

Gambar 1. Langkah kunci pengabdian yang dilaksanakan

\section{HASIL DAN PEMBAHASAN}

Isu perempuan merupakan isu tua, setua sejarah perkembangan pemikiran manusia (Ibrahim, 2005). Dunia saat ini percaya bahwa mendukung pengusaha perempuan sangat penting untuk pertumbuhan ekonomi. Peluang ekonomi meningkat, diiringi dengan masuknya perempuan ke dalam dunia bisnis dan kewirausahaan. Di Indonesia, perempuan memiliki sekitar 23\% usaha kecil dan menengah, dan proporsi usaha yang dimiliki oleh perempuan tumbuh secara signifikan lebih cepat daripada yang dimiliki oleh laki-laki (Asia-Pacific Economic Cooperation, 2013).

Pengusaha perempuan, seperti UMKM Indonesia pada umumnya, beroperasi di sektor informal, atau berada di tengahtengah antara formalitas dan informalitas (Stein et al., 2013). Ketika berwirausaha, penguasaan skill sangat penting dan dibutuhkan agar karier berwirausaha dapat berkembang dan lebih sukses (Frinces, 2010). Oleh sebab itulah, pemberdayaan perempuan mutlak diperlukan. Hal tersebut sejalan dengan prinsip ABCD yang menyatakan individu dalam komunitas memiliki aset untuk memobilisasi, mendorong, dan memengaruhi perubahan dari dalam (Kretzmann \& McKnight, 1993). Berikut kami sampaikan profil perempuan pengusaha Aisyiyah Kota Bandung yang mengikuti kegiatan pemberdayaan memanfaatkan media digital untuk penguatan ekonomi di masa pandemi covid 19: 
Tabel I. The sociodemographic features

\begin{tabular}{|c|c|c|}
\hline Item & $\mathbf{N}$ & $0.0 \%$ \\
\hline \multicolumn{3}{|l|}{ Gender } \\
\hline Female & 29 & 100 \\
\hline \multicolumn{3}{|l|}{ Age } \\
\hline Dewasa Awal 18-40 & 5 & 17,3 \\
\hline Dewasa Madya 40-60 & 22 & 75,8 \\
\hline Dewasa Akhir >60 & 2 & 6,9 \\
\hline \multicolumn{3}{|l|}{ Status Pernikahan } \\
\hline Belum Menikah & 1 & 3,4 \\
\hline Menikah & 23 & 79,3 \\
\hline Janda & 5 & 17,3 \\
\hline \multicolumn{3}{|l|}{ Education Background } \\
\hline Sarjana & 20 & 68,9 \\
\hline Diploma & 2 & 6,9 \\
\hline SMA/Sederajat & 7 & 24,2 \\
\hline \multicolumn{3}{|l|}{ PCA } \\
\hline Antapani & 13 & 40 \\
\hline Andir & 2 & 6 \\
\hline Astanaanyar & 2 & 6 \\
\hline Sukajadi & 2 & 6 \\
\hline Cibeunying Kidul & 4 & 12 \\
\hline Cibeunying Kaler & 2 & 6 \\
\hline Coblong & 2 & 6 \\
\hline Lengkong & 2 & 6 \\
\hline Gedebage & 2 & 6 \\
\hline Cinambo & 2 & 6 \\
\hline \multicolumn{3}{|l|}{ Jenis Usaha } \\
\hline Makanan & 16 & 55,1 \\
\hline Minuman & 1 & 3,4 \\
\hline Pakaian & 3 & 10,4 \\
\hline Kosmetik & 2 & 6,9 \\
\hline Asesoris & 1 & 3,4 \\
\hline Jilbab & 3 & 10,4 \\
\hline dll & 3 & 10,4 \\
\hline \multicolumn{3}{|l|}{ Memulai Usaha } \\
\hline Sebelum Pandemi & 21 & 72,4 \\
\hline Sesudah Pandemi & 8 & 27,6 \\
\hline \multicolumn{3}{|l|}{ Promosi } \\
\hline Bermedia & 26 & 89,6 \\
\hline Non Media & 3 & 10,4 \\
\hline
\end{tabular}

\section{Pemberdayaan ekonomi bagi aktivis perempuan}

Dalam memahami pertanyaan tentang teologi yang mendasari kaum perempuan untuk bergerak di bidang wirausaha, peserta terkecoh dengan QS Ali Imron Ayat 104, yang memang telah menjadi dasar teologi gerakan da'wah Aisyiyah, sebagai perempuan Muhammadiyah, tentang pentingnya berda'wah dan melibatkan diri dalam gerakan da'wah sehingga kaum muslimin akan memperoleh keunggulan secara kolektif. Di sisi lain, mayoritas peserta memahami bahwa persoalan ekonomi keluarga, merupakan persoalan bersama, yang secara umum ditunjukkan oleh fenomena pemutusan hubungan kerja yang cukup massif, yang dirasakan oleh sebagaian besar para pencari nafkah keluarga, yang secara langsung imbasnya dirasakan oleh kaum perempuan sebagai pengelola ekonomi keluarga, sehingga otomatis kaum perempuan harus berfikir mencari solusi atas persoalan ekonomi rumah tangganya.

Para aktivis perempuan mengambil peran dengan terjun melakukan usaha-usaha kreatif, alih-alih menyerah pada keadaan dan marah pada pemerintah yang dianggap harus bertanggungjawab atas keadaan ekonomi warganya. Sebagai aktivis sosial keagamaan, sebagian besar sudah memahami kewajiban untuk membangun karakter entrepreneurship karena karakteristiknya sangat sangat mirip, tetapi berbeda dalam konteks dan orientasi kegiatannya. Mereka telah memahami bahwa untuk menjadi sukses dalam berwirausaha, memerlukan karakter mandiri, optimis dan tekun dalam menjalankan usaha, bersikap tabah menghadapi berbagai problem usaha yang dipastikan selalu ada di setiap langkah usaha, yang harus ditanggung sebagai resiko usaha. 
Sedangkan untuk langkah-langkah penting yang harus dilakukan oleh aktivis perempuan dalam mewujudkan ekonomi kreatif dan kewirausahaan, sudah sesuai, hanya saja masih sedikit sekali peserta yang masih terjebak dalam mitos bahwa menjadi pengusaha itu hanya sekedar memerlukan talenta alias bakat semata. Sementara mayoritas peserta telah mempercayai bahwa membangun jejaring dan menguasai akses pada pasar online merupakan modal untuk dapat memulai bisnis menjadi wirausahawan. Memang telah dibuktikan bahwa pengusaha adalah salah satu profesi yang dapat dilakukan oleh siapa saja, selama mereka mau melalui proses belajar dan mempraktikkan langsung hasil belajarnya, yang bahkan dapat terjadi perbedaan antara teori yang dipelajari dengan praktik. Secara umum, meskipun UMKM masih kurang terwakili dan menampilkan produktivitas rendah, sektor ini telah berkembang lebih dinamis daripada segmen mikro dan korporasi.

\section{Digital marketing sebagai media promosi}

Pelaku usaha di Aisyiyah sudah memiliki pengetahuan tentang pemasaran melalui digital sebagai media promosi yang efektif, terutama di masa pandemi Covid 19 dimana transaksi penjualan secara tatap muka sangat terbatas, sehingga interaksi antara penjual dan pembeli memang harus lebih banyak dialihkan pada pemanfaatan media digital. Peserta mengetahui bahwa pemasaran digital tidak hanya membutuhkan pengetahuan tentang pasar, pemasaran dan promosi saja, namun juga yang terpenting ialah pengetahuan tentang teknologi digitalnya itu sendiri, termasuk pemilahan antara pemasaran digital dan pemasaran konvensional untuk dapat menjangkau target pasar yang lebih luas dengan memanfaatkan berbagai saluran/platform potensial. Menurut Cirucci (2018), perempuan sangat aktif berinteraksi di media sosial. Akan tetapi, penggunaan media sosial bagi perempuan lebih sering digunakan untuk sesuatu yang bersifat emosional, seperti liking (memberi tanda "suka" atau love di posting-an seseorang) atau mengomentari sebuah topik yang memancing sisi emosionalnya. Oleh karena itu, pengenalan aneka platform media sosial dan gambaran konten yang dapat disajikan penting sekali untuk dilakukan. Pelaku usaha di Aisyiyah Jawa Barat sudah mengenal media sosial lebih dari sekadar kebutuhan emosional saja. Bisnis online memiliki potensi besar dalam memberdayakan perempuan dengan mendampingi mereka menjadi wirausaha. Bisnis online juga dapat dilihat sebagai solusi atas dilema yang saat ini tengah dihadapi oleh para wanita yang harus mengatur dan menyeimbangkan karir dan kehidupan keluarganya (Melissa et al., 2013).

\section{Media sosial dan promosi}

Peserta PKM telah mengetahui karakteristik media sosial yang tidak sama dengan media konvensional. Tidak adanya organisasi yang kompleks dalam media sosial diketahui dengan tepat oleh peserta. Selain itu, peserta juga mengetahui dan memahami bahwa media sosial jauh lebih fleksibel, interaksi dua arah, dan lain-lain. Karaktertistik itu dipahami benar oleh peserta karena peserta telah mampu menggunakan fitur-fitur yang dapat dimanfaatkan untuk promosi produk. Bahkan, dalam penggunaan beberapa platform media sosial yang saat ini tengah banyak digandrungi oleh masyarakat pun peserta PKM telah mengetahui dan memahami dengan baik. Media sosial sebagai gerbang akselerasi pemberdayaan perempuan (Kadeswaran et al., 2020).

Peserta PKM mengetahui produk apa yang cocok untuk dijual atau dipromosikan di Facebook, Twitter, Instagram, dan lain-lain berdasarkan usia dan minat audiens dari tiap platform tersebut. Misalnya, di Facebook peserta telah mengetahui bahwa fitur di Facebook dapat dimanfaatkan untuk unggah foto dan video kreatif yang disertai caption yang panjang dan detail. Walau, peserta PKM masih keliru dalam membaca peluang diberikan Twitter karena peserta berpikir bahwa Twitter strategi untuk berjualan kosmetik, padahal Twitter paling tepat digunakan untuk promosi produk olahraga karena pengguna laki-laki lebih banyak dibanding pengguna Twitter perempuan. Salah satu cara promosi di media sosial adalah menggunakan storytelling. Peserta kegiatan PKM memahami fungsi storytelling yang begitu dekat dengan manusia, yaitu mengikat emosi yang membaca sebuah cerita. Apalagi, kekuatan cerita pun diakui oleh peserta PKM lebih kuat dibanding statistik. 


\section{Konten marketing}

Di negara berkembang termasuk Indonesia, media sosial menjadi peluang yang sangat berharga. Karakteristik media sosial yang fleksibel dan terbuka menjadi peluang baru bagi para perempuan yang berwirausaha. Selain untuk promosi produk, terciptanya bisnis baru yang dijalankan perempuan dapat terwujud berkat fleksibilitas dan atribut media sosial. Media sosial memfasilitasi penyebaran informasi, opini, dan konten, serta mempromosikan interaksi sosial antar individu, dan antara individu dan organisasi (Kadeswaran et al., 2020).

Media sosial juga memungkinkan para perempuan yang berwirausaha mengeksplorasi konten dengan lebih kreatif. Konten yang kreatif akan memberikan peluang yang besar agar produk dikenali. Hal ini juga akan menambah kualitas hidup dari para perempuan. Seperti yang dikatakan oleh Suwana dan Lily (2017), penguasaan media sosial bagi perempuan meliputi kemudahan dan kemampuan mengakses, mencari dan menganalisis konten yang dibutuhkan, merefleksikan dengan kebutuhan atau kehidupan sehari-hari, termasuk kemampuan membagi dan menciptakan konten. Konten marketing adalah strategi pemasaran yang dibuat untuk merencanakan, membuat, dan mendistribusikan muatan atau isi dari produk kita yang mampu menarik audiens secara tepat sasaran. Dengan ketepatan itu diharapkan dapat menarik para pelanggan (Kotler et al., 2017). Hanya 7 peserta (24,2\%) yang menjawab benar. Sebagian besar peserta (75,8\%) menjawab bahwa tujuan konten marketing adalah untuk menjual atau mempromosikan merek usaha. Padahal esensi konten marketing tidak bertujuan untuk menjual tetapi untuk membantu audiens memahami merek dan membangkitkan minat. Pembedaan antara copywriting dan content marketing masih bercampur dalam pengetahuan peserta.

\section{KESIMPULAN}

Melalui prinsip $\mathrm{ABCD}$ yang diterapkan terbukti bahwa perempuan mampu berdaya dalam kegiatan wirausahanya, terutama para aktivis Aisyiyah Kota Bandung. Pendampingan ini menemukan bahwa ada bibit atau aset-aset unggul yang telah dimiliki para perempuan aktivis Aisyiyah dalam hal ini wirausaha. Aset-aset inilah yang coba dikembangkan. Dari aset yang telah dimiliki dan berbekal semangat yang menjadi mimpi mereka, pendampingan ini fokus pada hal-hal yang mereka perlukan. Dari situlah, konseptual desain pendampingan dirumuskan denga melakukan langkah-langkah strategis, seperti pelatihan dan pendampingan terus menerus dalam grup WhatsApp. Dari pendampingan yang intens ini, kemajuan ataupun hambatan para aktivitas Aisyiyah dalam berwirausaha dimonitoring.

\section{UCAPAN TERIMA KASIH}

Penulis menyampaikan ucapan terimakasih kepada Universitas Islam Bandung atas pelaksanaan kegiatan pengabdian ini.

\section{REFERENSI}

Anas, J., Ferrara, L. 2004. Detecting Cyclical Turning Points: The ABCD Approach and Two Probabilistic Indicators. Journal of Business Cycle Measurement and Analysis. 2004(2):193-225. https://doi.org/10.1787/jbcma-v2004-art12-en

Asia-Pacific Economic Cooperation. 2013. Access to Trade and Growth of Womenât $\epsilon^{T \mathrm{M}_{\mathcal{S}}}$ SMEs in APEC Developing Economies. Singapore: The Asia Foundation.

Chib, A., May, J., Barrantes, R. 2015. Impact of Information Society Research in the Global South. Cham: Springer Nature. https://doi.org/10.1007/978-981-287-381-1_1

Cirucci, A.M. 2018. A New Woman's Work: Digital Interactions, Gender, and Social Network Sites. International Journal of Communication. 12:2948-2970.

Frinces, Z.H. 2010. Pentingnya Profesi Wirausaha di Indonesia. Jurnal Ekonomi dan Pendidikan. 7(1):34-57. http://dx.doi.org/10.21831/jep.v7i1.576 
Hanafi, S.M., Sobirin, A. 2002. Relevansi Ajaran Agama Dalam Aktivitas Ekonomi. Iqtishad Journal of Islamic Economics. 3(1):16-34. https://doi.org/10.20885/iqtisad.vol3.iss1.art2

Ibrahim, Z. 2005. Psikologi Wanita. Bandung: Pustaka Hidayah.

Indayani, S., Hartono, B. 2020. Analisis Pengangguran dan Pertumbuhan Ekonomi sebagai Akibat Pandemi Covid-19. Perspektif : Jurnal Ekonomi dan Manajemen Akademi Bina Sarana Informatika. 18(2):201-208. https://doi.org/10.31294/jp.v17i2

Indiworo, H.E. 2016. Peran Perempuan Dalam Meningkatkan Kinerja UMKM. 1(1):40-58. https://doi.org/10.26877/ep.v1i1.1806

Kadeswaran, S., Brindha, D., Jayaseelan, R. 2020. Social Media as a Gateway for Accelerating Women Empowerment. Parishodh Journal. 9(3):4876-4885.

Kotler, P., Kartajaya, H., Setiawan, I. 2017. Marketing 4.0: Moving from Traditional to Digital. New Jersey, US: John Wiley \& Sons Inc.

Kretzmann, J.P., McKnight, J.L. 1993. Building communities from the inside out: A path toward finding and mobilizing a community's assets. Chicago, US: ACTA Publications.

Melissa, E., Hamidati, A., Hamidati, M.S. 2013. Social Media Empowerment: How Social Media Helps to Boost Women Entrepreneurship in Indonesian Urban Areas. IAFOR Journal of Media, Communication and Film. 1(1):77-90. https://doi.org/10.22492/ijmcf.1.1.06

Stein, P., Ardic, O.P., Hommes, M. 2013. Closing the Credit Gap for Formal and Informal Micro, Small, and Medium Enterprises. Washington, US: International Finance Corporation.

Suwana, F., Lily. 2017. Empowering Indonesian Women through Building Digital Media Literacy. Kasetsart Journal of Social Science.38(3):1-6. https:// doi.org/10.1016/j.kjss.2016.10.004

Tambunan, T. 2012. Usaha Mikro Kecil dan Menengah di Indonesia: Isu-isu Penting. Jakarta: LP3ES.

Vivakaran, M.V., Maraimalai, N. 2017. Feminist pedagogy and social media: a study on their integration and effectiveness in training budding women entrepreneurs. Gender and Education. 29(7):869-889. https://doi.org/10.1080/09540253.2016.1225008 